\title{
The Effect of Tramadol on the Peristaltic Movement Small Intestine in Rabbit
}

\author{
Maha K. AL- Jameel Ghada A. Taqa \\ Department of Dental Basic Sciences \\ College of Dentistry \\ Mosul University
}

\author{
Mohammad Y. AL-Fathee \\ Department of Biology \\ College of Education \\ Mosul University
}

(Received 13/ 12 / 2010 ; Accepted 25 / 4 / 2011 )

\begin{abstract}
Tramadol is an opium analgesic drug that is used to relieve moderate to relatively severe pain. The major side effect of opium analgesic drugs is inhibit the intestinal peristalsis motility, and the effect of tramadol on gut motility is unknown quitely, therefore the effect of tramadol on intestinal peristalsis in vitro was examined in segments of the rabbit small intestine. Our study demonstrated that the low concentration of tramadol $(0.1$, $0.2,0.3,0.4,0.5) \mathrm{ml}$, escort to activation peristalsis movement while increase the concentration $(0.6,0.7,0.8,0.9,1.0) \mathrm{ml}$ lead to decrease the contraction but when increase the concentration to $1 \mathrm{ml}$ lead to inhibited the peristalsis movement and complete relaxation. There for the study was concluded that the tramadol uses on rabbit small intestine decrease the peristalsis movement and this inhibition depend on concentration manner.
\end{abstract}

Keywords: Tramadol, peristalsis movement, opioid analgesic, low concentration, High concentration

\section{درلمة تأثثير عقار الترامادط عل حركة التحوي للأمعاء القيقةف الأرنب}

\section{الملغص}

الترلمادول عقار أفيوني مسكن يستخدم في علاج الآلام المتوسطة والحادة. لحد اهم التأثيرات الجانبية

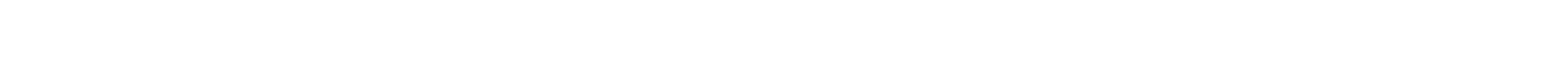



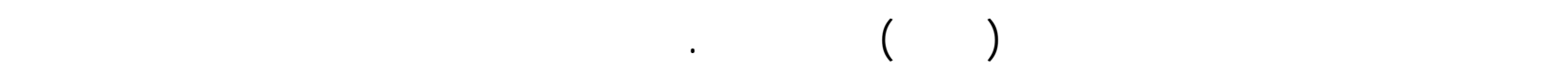

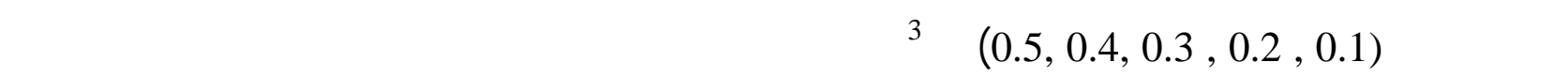


الارتخاء، بينما أدى إعطاء التركيز العالي

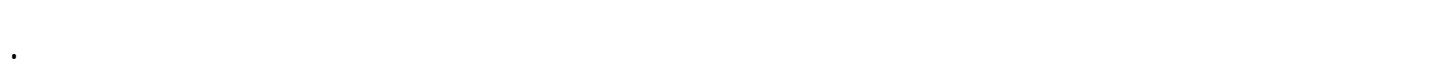




\section{INTRODUCTION}

Smooth muscle makes up the visceral or involuntary muscle. The innervation of smooth muscle is provided by the autonomic nervous system, there are two responses in smooth muscle, many smooth muscle respond by constant contraction with long period called tonic contraction, another one called phasic contraction, its respond by short and constant contraction, with inhibition (Lincoln, 2005 ).

Two broad types of smooth muscle can be distinguished on the basis of the type of stimulus which results in contraction and the specificity with which individual smooth muscle cells react to the stimulus:

1. The multiunit type represents functionally independent smooth muscle cells which are often innervated by a single nerve terminal and which never contract spontaneously (e.g. smooth muscle in the walls of blood vessels).

2. The visceral type represents bundles of smooth muscle cells connected by gap P junctions, which contract spontaneously if stretched beyond a certain limit e.g. smooth muscle in the walls of the intestines (Ganong, 2003).

Tramadol is a new synthetic centrally acting opium analgesic used mainly for treatment moderate to severe pain (Katzung, et al., 2009). Tramadol is produce its multimodal antnociceptive and analgesic effects via two mechanisms ( Raffa and Friderichs , 1996 ): one is opium, and other in nonopioid (Ide et al., 2006 ). The opium component involves weak affinity for $\mathrm{mu}(\mu)$ opium receptor (Gillen et al., 2000). The nonopioid component is related to inhibition of neuronal 5-hydroxytryptamine (5-HT; serotonin) and norepinephrine reuptake (Codd et al.,1995). The use of opioids is accompanied by serious side effects such as inhibition of gastrointestinal motility (Wheeler et al., 2002). As a result several strategies to provide opium bowel dysfunction have been envistigate. In particular, opium -like compounds with a reduce impact on intestinal function and opioid receptor antagonist with a peripherally restricted site of action have been developed (Holzer, 2004). Tramadol is a centrally acting synthetic 4-phenylpiperidine analogue codeine, which has become available as an analgesic for treatment of moderate to severe pain such as postoperative (Scott and Perry , 2000) neuropathic (Sindrup , 1999) and osteoarthritis (Wilder-Smith et al., 2001) as well as in patient suffering from chronic pancreatitis(Wilder-Smith et al., 1999). However the controversial information as to whether tramadol has an inhibitory action on gut motility little known

The present investigation was undertaken to study the inhibitory effect of tramadol on peristalsis movement in experimental rabbit's small intestine.

\section{MATERIALS AND METHODS}

Healthy local rabbits type Oryctolagus cuniculus of either sex weighting $1.5-1.75 \mathrm{Kg}$ were selected for the study. The animals were housed under laboratory condition at temperature $22 \pm 2 \mathrm{C}^{\circ}$ with a natural light $\backslash$ dark cycle and fed with standard diet, vegetable, crushed wheat, corn and water. Until the time of experiment. Animals were sacrificed by cervical dislocation, and the ileum were excised, flushed of lumen content and placed in Tyrodes solution at room temperature gassed with 95\% O2 and 5\% Co2 until used. 
For studying peristalsis, the distal small intestine was divided into segments, each being approximately (2-3) cm long. The intestinal segments were set up longitudinally in organ bath containing normal physiology ( Tyrodes solution ) $50 \mathrm{ml}$ at $37 \mathrm{C}^{\circ}$ for half hours before experiment to stabilize the tissue. Record the activity of intestinal smooth muscle by using Chromatography device ( speed 2 ), after fixation the segment in organ bath and the intestinal segments was tied to an inflow cannula, which permitted to continuous infusion of per warmed standard solution at flow rate $0.5 \mathrm{ml} \backslash$ minute. After basal peristaltic activity had been record for at least 30 minute, the drugs to be tested were administered to the bath, on the surface of intestinal segments by insulin disposable syringe.

Note : Tramadol is used as ampoule $(1.0 \mathrm{ml}, 50 \mathrm{mg} / \mathrm{ml})$, that is mean $0.1 \mathrm{ml}$ include $5 \mathrm{mg}, 0.2$ include $10 \mathrm{mg}$ extra.

\section{RESULTS}

In the present study, the peristalsis movement was evaluated after administration tramadol on the solution (Tyroid solution) of intestinal segments of rabbits inside the organ bath. Under control condition regular peristalsis contraction were records that stayed constant and were not influenced by the addition of (Tyroid solution). Figure 1: recording the effect of tramadol on the intestinal motility after added tramadol at dose $(0.1,0.2,0.3$, $0.4,0.5$ ) $\mathrm{ml}$ to the organ bath and this doses lead to an increase of peristalsis movement in a concentration - related manner while tyroid solution did not affected on peristalsis contraction luminal perfusion of isolated segments of the rabbits small intestine slowly increased the intraluminal pressure; when the peristaltic pressure marked. It was transiently enhanced by $0.1 \mathrm{ml}$ tramadol.

Fig. 1 : more pronounced increase of PPT was caused by 0.2 -- $0.3 \mathrm{ml}$ tramadol. An increase in the frequency of peristaltic waves was also observed. Spike like increase of intraluminal pressure was triggered .

Fig. 2 : demonstrated that the peristalsis movement was already inhibited by adding highly concentration of tramadol $(0.6,0.7,0.8,0.9,1.0 \mathrm{ml})$ and the peristalsis movement as complete absence of any motor activity after added high concentration of tramadol 1.0 $\mathrm{ml}$.

Fig. 3 : demonstrated the complete and continues activity of tramadol from $(0.1,0.2$, 0.3 ------- 1.0) $\mathrm{ml}$, the Figure show the increase of peristalsis movement in a low concentration, then the inhibiter of peristalsis movement in a high concentration, and the complete absence of any motor activity after added $1.0 \mathrm{ml}$ of drug .

Note :

$\mathrm{C}=$ control .

Arrows ( $)$ indicate the pointed of adding the drug concentrations. 


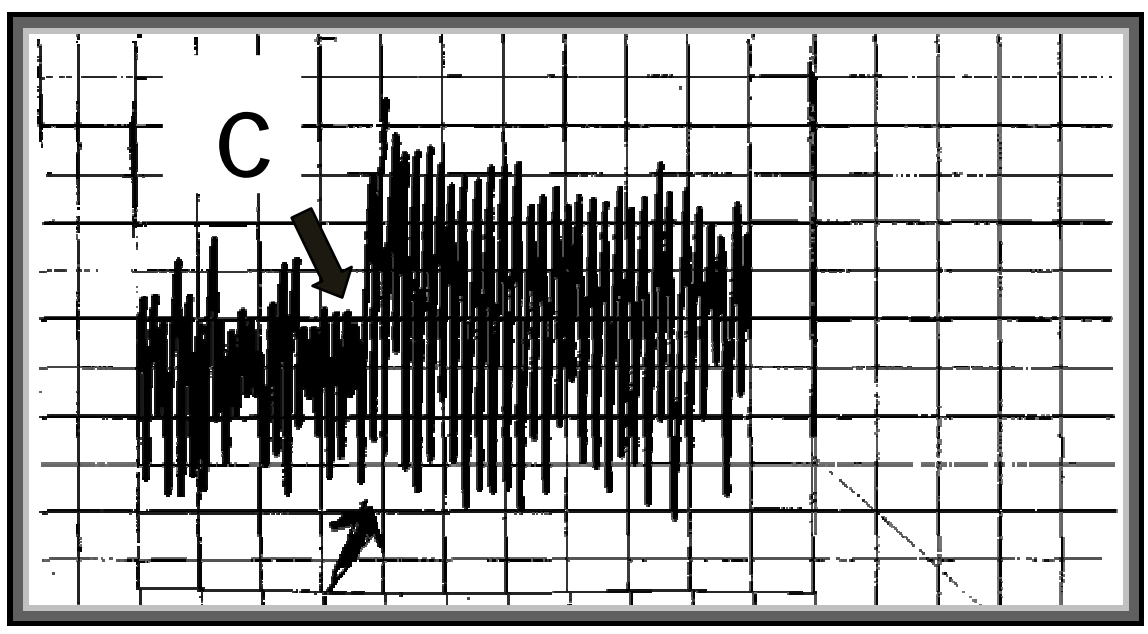

$0.1 \mathrm{ml}$

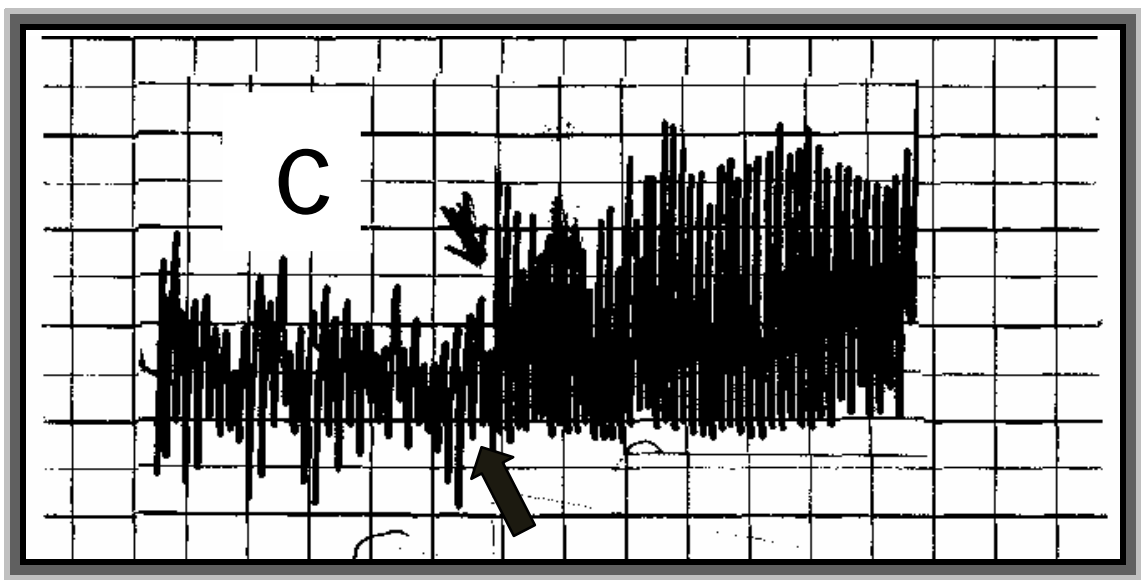

$0.2 \mathrm{ml}$ 


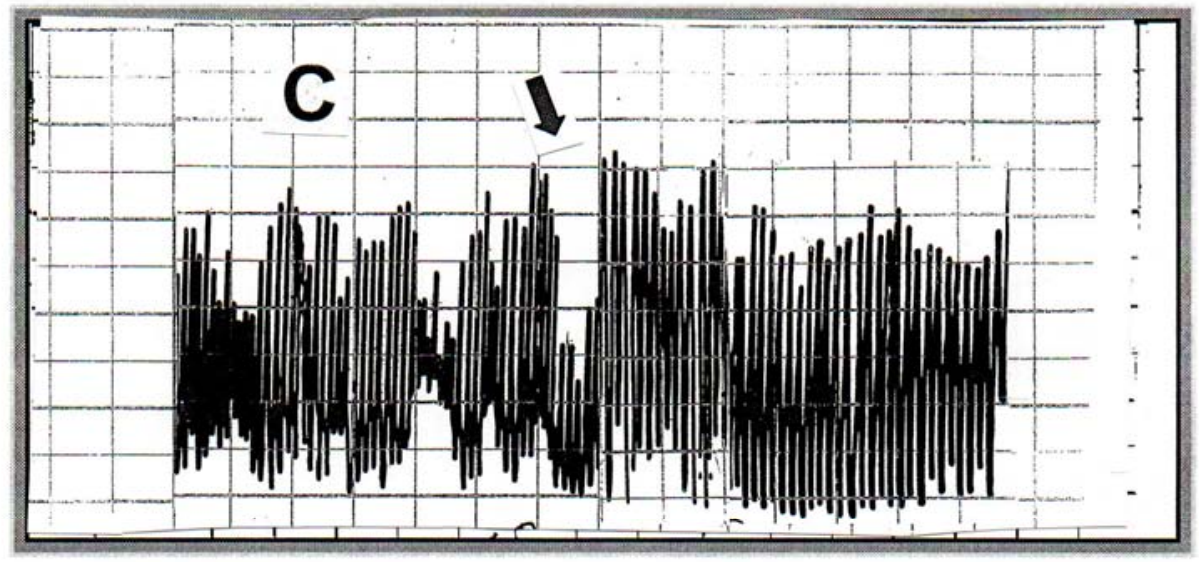

\section{$0.3 \mathrm{ml}$}

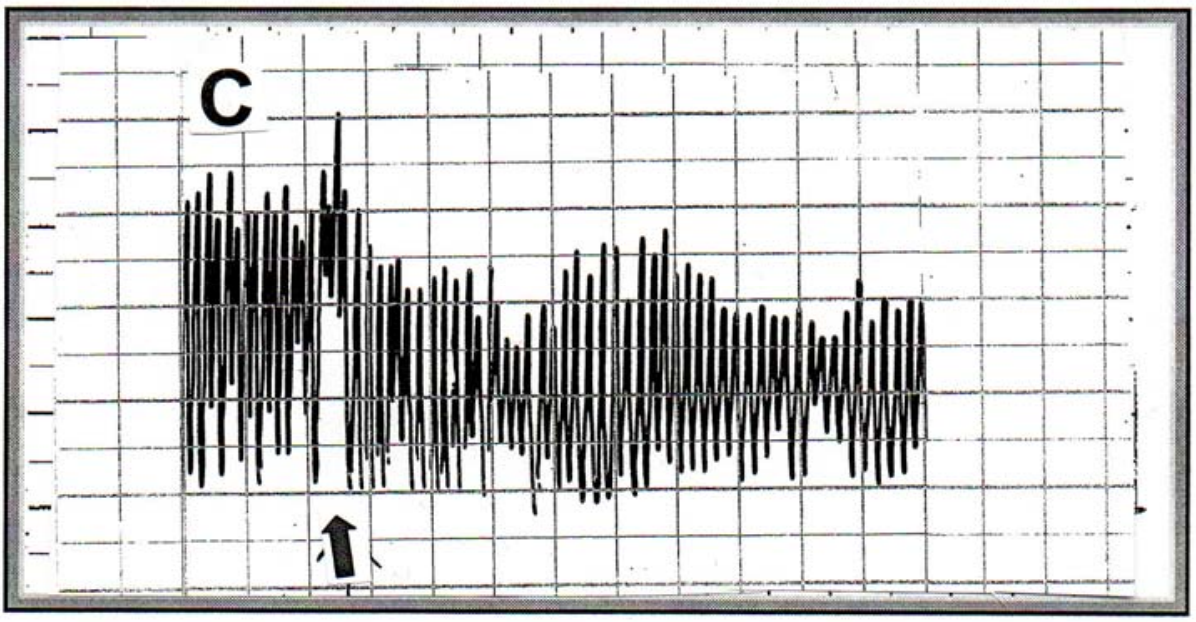

$0.4 \mathrm{ml}$

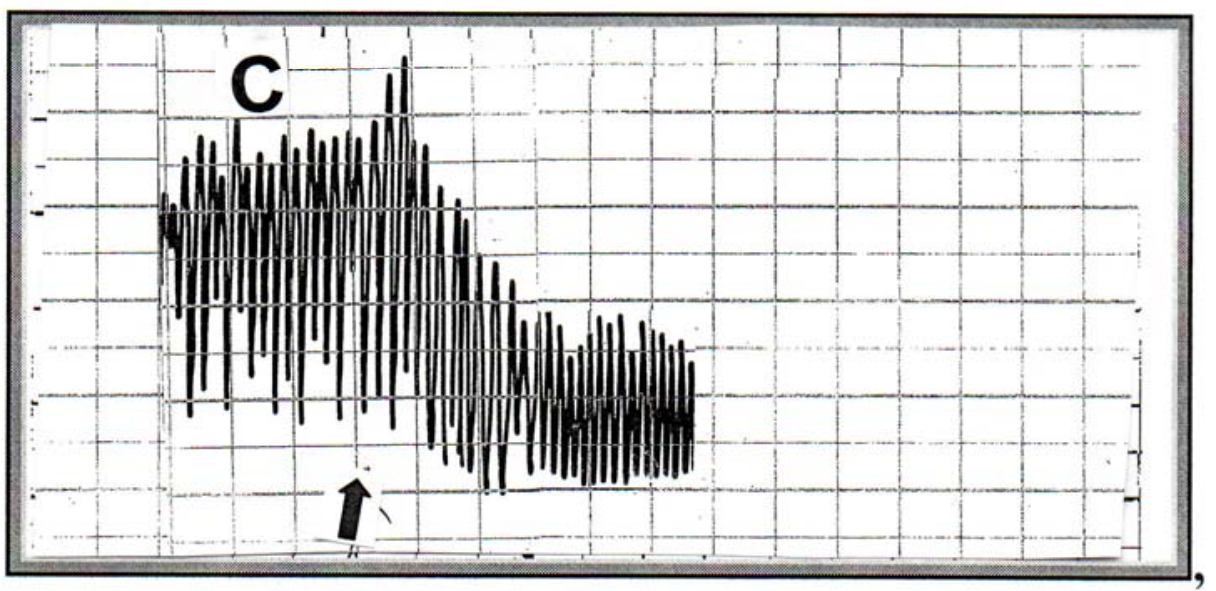

$0.5 \mathrm{ml}$

Fig. 1: recording the effect of tramadol on the intestinal motility after added tramadol at dose $(0.1,0.2,0.3,0.4,0.5) \mathrm{ml}$. 




\section{$0.6 \mathrm{ml}$}

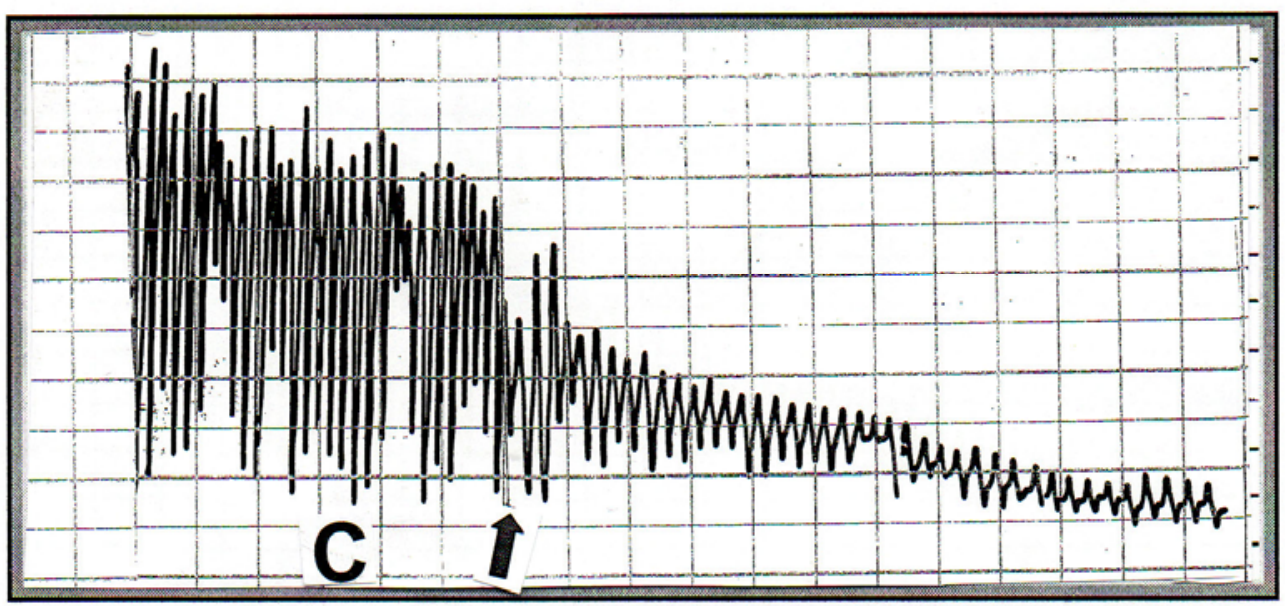

\section{$0.7 \mathrm{ml}$}

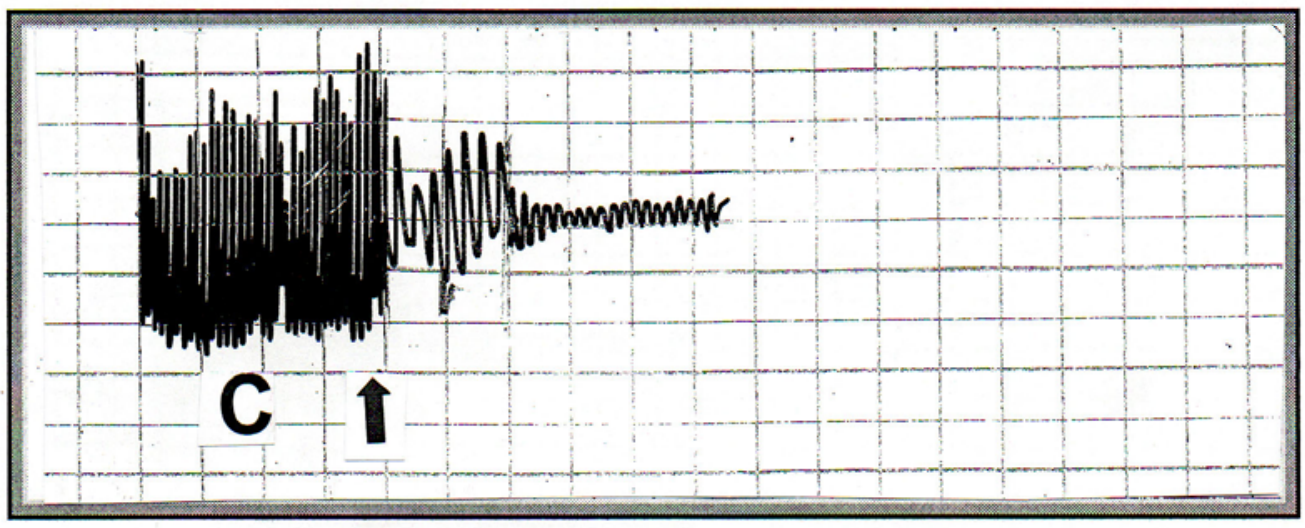

$0.8 \mathrm{ml}$ 


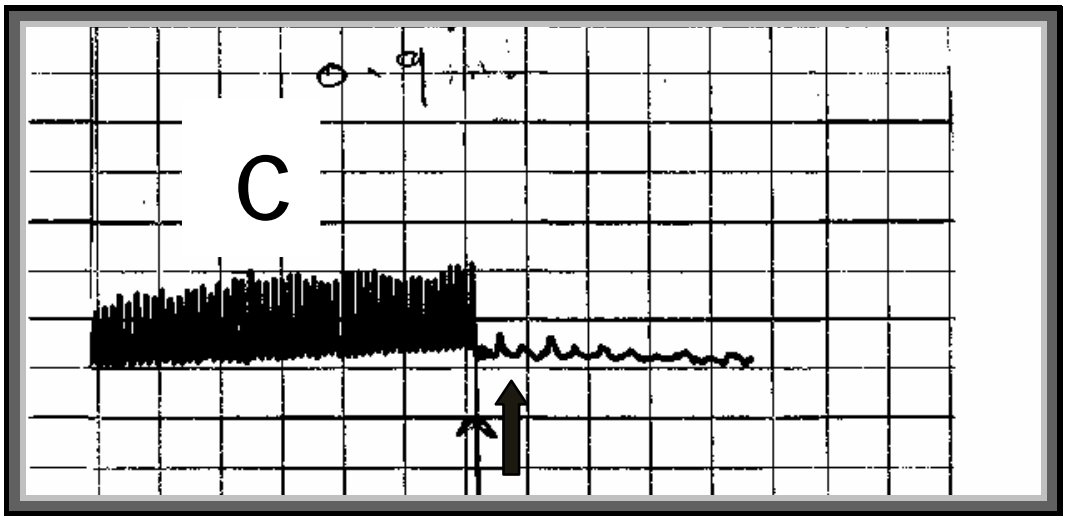

$0.9 \mathrm{ml}$



$1.0 \mathrm{ml}$

Fig. 2 : demonstrated that the peristalsis movement was already inhibited by adding highly concentration of tramadol $(0.6,0.7,0.8,0.9,1.0) \mathrm{ml}$

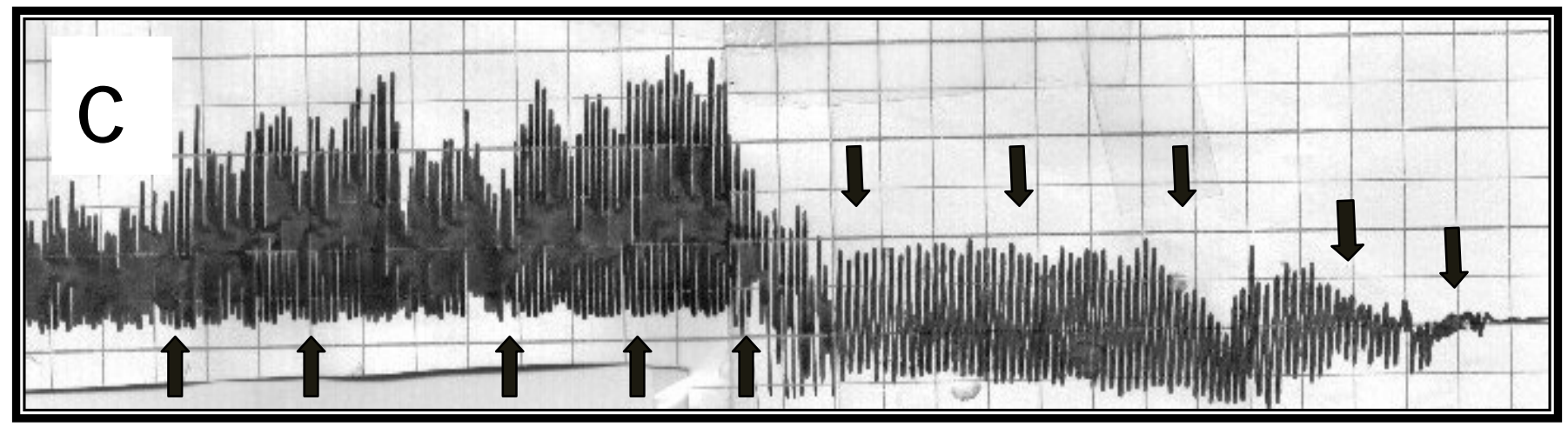

$\begin{array}{llllllllll}0.1 \mathrm{~m} & 0.2 \mathrm{ml} & 0.3 \mathrm{ml} & 0.4 \mathrm{ml} & 0.5 \mathrm{ml} & 0.6 \mathrm{ml} & 0.7 \mathrm{ml} & 0.8 \mathrm{ml} & 0.9 \mathrm{ml} & 1.0 \mathrm{ml}\end{array}$

Fig. 3: demonstrated the complete and continues activity of tramadol from $(0.1,0.2,0.3$--1.0) $\mathrm{ml}$. 


\section{DISCUSSION}

Our study demonstrate that the tramadol impaired intestinal peristalsis movement in a concentration - dependent manner as deduced from an increase in the peristaltic pressure threshold and this result agreement with others study that suggest that tramadol impaired intestinal peristalsis contraction in a concentration - dependent (Herbert et al., 2007).

Our study finding that the high concentration of tramadol completely abolished the intestinal peristalsis movement and this result agreement with others study that suggest the patient suffering cancer have shown that tramadol has a constipating effect ,however is less than that morphine this due to the inhibit peristalsis movement (Wilder-Smith et al., 1994). The most of inhibitory effect of tramadol on gut motility depend on opioid receptor activation ( Alonne et al., 2004 ). The cause of this inhibition return to the action of opioid at the molecular level, opium receptor form a family of proteins that physically couple to G-proteins and through this interaction affect on ion channel gating (Katzung et al., 2009). Opium after binding to opium receptor suppression of adenyl cyclase activity, and activation of receptor likned with $\mathrm{K}$ ion currents and suppression of voltage-gate of $\mathrm{Ca}$ ion currents. the hyperpolarization of membrane potential by $\mathrm{K}$ current activation and the limiting of Ca entry by suppression of Ca current (Lourence and Keith , 2008), many studies indicated that the activity effect by many drugs related to increase the flow of $\mathrm{Ca}$ ion through the effect of this ion on calcium channel which present inside cell membrane (Gourgoulianis et al., 2004 ) this causing inhibition of neurotransmitter release such as glutamate, serotonin, norepinephrine and also decrease the release of Acetylcholin (Ach) which responsible for contraction of small intestine (Wang et al., 1994; Harvey and Champe , 2009 ) as well as the contraction of smooth muscle depend on Ca ion (Castels , 1980 ) because Ca ion play a main role in contraction- relaxation mechanism of smooth muscle (Seeley et al., 1998 ) and may be inhibiting ligand gate Ca channel by opioid prevent the enter of Ca ion may be prevent smooth muscle contraction and this lead to relaxation of smooth muscle and decrease the intestinal peristalsis contraction and in high dose abolish this contraction.

\section{CONCLUSION}

Over all, the obtained results demonstrate that tramadol is more potent in inhibiting peristalsis movement of experimental rabbit's small intestine and the action of tramadol depends on it's concentration.

\section{REFERENCES}

Alonne, H.; Coffiner, M.; Sonet, B.; Sereno, A.; Vanderbist, F.(2004). Efficacy and tolerability of sustained - release tramadol in the treatment of symptomatic osteoarthritis of the hip or knee : a multicenter, randomized, double - blind , placebo- study . Clin Ther. 26, 1774-1782.

Castel, R. (1980). Electro and pharmacomechanical coupling in vascular smooth muscle . Chest , 78(supp 1) , 150-156.

Codd, E.E.; Shank, R.P. ; Schupsky, J.J. ; Raffa, R.B. (1995). Serotonin and nor epinephrine uptake inhibiting activity of centrally acting analgesics : Structural 
determinants and role in antinociception. J. Pharmacol. Exp. Ther. 274, 12631270.

Ganong , W .F. (2003). "Review of Medical Physiology" , 21 th edn. McGraw -Hill ,California. pp . 82-85 .

Gillen, C.; Haurand, M.; Kobelt, D.J. ; Wnendt, S. (2000). Affinity, potency and efficacy of tramadol and its metabolites at the cloned human-opioid receptor . N-S Arch Pharmacol. 362, 116-121.

(Gourgoulianis, K. I. ; Chatziparasidis, G. ; Chatziefthimiou, A.; Molyvadas, P. A. ( 2004). Magnesium as a relaxing factor of airway smooth muscles. J. Aerosol Med . , 14(3), 301-307.

Harvey, R.A.; Champe, P.C. (2009 ). "Lippincott's Illustrated Reviews: Pharmacology". 4th edn. Walters Kluwer Company Philadelphia . London . 161p.

Herbert, M. K. ; Weis, R. ; Holzer, P. (2007). The enantiomers of tramadol and its major metabolite inhibit peristalsis in the guinea pig small intestine via differential mechanisms . BMC Pharmacol. 10,1186/1471-2210-7-5.

Holzer, P. (2004). Opioid and opioid receptors in the enteric nervous system: from a problem in opioid analgesia to a possible new prokinetic therapy in humans. Neurosci Lett. 361,192-195.

Ide, S.; Minami , M.; Ishihara, K.; Uhl, G.R.; Sora, I. ; Ikeda, K. (2006). Mu opioid receptor- dependent and independent component in effect of tramadol. Neuropharmacology . 51, 651-658.

Katzung , B.G.; Master , S.B. ; Trevor, A.J. (2009). Basic and clinical pharmacology . 11edn . Basicconcentration. Copyright . McGraw - Hill Companies ., California , 547p.

Lincoln, T. M. ( 2005 ). Additional notes on smooth muscle lecture. http:// physiology. usouthal edu / handouts / smooth muscle .pdf

Lourence, L. B. ; Keith, L. P. (2008). "Manual of Pharmacology and Therapeutic. Copyright" . McGraw - Hill Companies ., California , 351p.

Raffa, R.B. ; Friderichs, E. (1996). The basic science aspect of tramadol hydrochloride. Pain Revs 3, 249-271..

Scott, L. J. ; Perry, C.M . (2000). Tramadol: a review of its use in perioperative pain. Drug. 60, 139-176.

Seeley, R.R. ; Stephens, T. D. ; Tate, P. (1998). "Anatomy and Physiology" , 4th edn. McGraw- Hill companies ., California , pp. 292-296.

Sindrup , S.H.; Andersen , G.; Madsen, C.; Smith, T.; Brosen, K. ; Jensen, T.S. (1999). Tramadol relieves pain and allodynia in polyneuropathy: a randomized, doubleblind, controlled trial. Pain. 83, 85-95.

Wang , J.; Verchere , C.B. ; MeInstoch, C.H. ; Brown, J.C . (1994). Characterization of acetylcholine induced increase in cytosolic free calcium contraction in individual rat pancreatic beta-cells. Cell Adhes Commun., 1(4), 343-353.

Wheeler , M.; Oderda , G.M.; Ashburn , M.A. ; Lipman , A.G. (2002). Adverse events associated with postoperative opioid analgesia : a systematic review . J. Pain. 3, 159-180.

Wilder-Smith , C.H.; Schimke , J.; Osterwalder, B. ; Senn H. J . (1994). Oral tramadol , a mu-opioid agonist and monoamine reuptake-blocker, and morphine for strong cancer-related pain. Ann Oncol. 5, 141-146. 
Wilder-Smith , C.H.; Hill , L. ; Osler , W. ; O'Keefe , S . (1999). Effect of tramadol and morphine on pain and gastrointestinal motor function in patients with chronic pancreatitis . Dig Dis Sci. 44, 1107-1117.

Wilder-Smith , C.H.; Hill , L.; Spargo , K. ; Kalla A. (2001). Treatment of severe pain from osteoarthritis with slow-release tramadol of dihydrocodeine in combination with NSAID's : a randomised study comparing analgesia , antinociception and gastrointestinal effects . Pain . 91, 23-31. 